\title{
Investigation into paediatric bilirubin analyses in Australia and New Zealand
}

\author{
LR WATKINSON, A ST JOHN,* LA PENBERTHY \\ From the Department of Clinical Biochemistry, Flinders Medical Centre, Bedford Park, South Australia \\ $5042 S A$
}

SUMMARY A small regional survey of direct spectrophotometric methods and a larger Australian and New Zealand survey of paediatric bilirubin analyses are described. The overall performance of both groups was unsatisfactory with an unacceptable high interlaboratory variation. This interlaboratory variation was reduced significantly by the use of a spectrophotometric method with a common standard of methyl orange.

The Australian and New Zealand survey also examined the "state of the art" for the measurement of conjugated bilirubin and showed that laboratories could not adequately measure conjugated bilirubin.

The need for paediatric bilirubin analyses to be performed with small imprecision and little or no inaccuracy has been discussed by $\mathrm{St}$ John and Penberthy ${ }^{1}$ and Blijenberg and Leijnse. ${ }^{2}$ There is also a need for interlaboratory agreement of results so that the problems of transferring babies to special care hospitals are eliminated.

In a previous small regional survey ${ }^{1}$ we showed that the performance of the group was unsatisfactory and gave an unacceptably high interlaboratory variation. It was suggested that further investigation of this problem particularly in the areas of method simplification and the use of common standards may improve the performance of these analyses.

Hertz et $a l^{3}$ critically examined a number of direct spectrophotometric methods and recommended two methods as being the most acceptable for measuring total plasma bilirubin. We have further investigated these methods to determine whether their use improves the performance of paediatric bilirubin analyses.

It is axiomatic that if laboratories in an interlaboratory survey use the same standard then the interlaboratory variation will be less than when participants use a variety of standards. One of the difficulties with bilirubin analyses is the choice of standard material and we have previously discussed

* Present address: Department of Clinical Biochemistry, Royal Perth Hospital, Perth, Western Australia 6000 WA.

Accepted for publication 4 June 1981 the problems associated with lyophilised sera and pure bilirubin standards. ${ }^{1}$ Jackson $^{4}$ demonstrated the use of recrystallised, dried methyl orange in neutral solution as a secondary standard. Such a standard in combination with a direct spectrophotometric method should minimise the problems of standardisation and so we have investigated the practical use of this material.

If laboratories were widely to adopt direct reading procedures such as spectrophotometric methods or some brands of "bilirubinometers" then this raises the problem of assaying conjugated bilirubin (bilirubin esters). Many laboratories maintain the use of diazo coupling techniques because they assay for both total bilirubin and conjugated bilirubin. Consequently the "state of the art" for the analysis of plasma conjugated bilirubin requires examination.

With the above problems to investigate we conducted:-

1 a small regional survey to investigate the use of $N$ direct spectrophotometric methods.

2 a survey of Australian and New Zealand laboratories where we have examined:

(i) the state of the art for this larger group,

(ii) the use of direct spectrophotometric methods by the group,

(iii) the use of a methyl orange secondary $\frac{T}{0}$ standard with the direct spectrophotometric $\frac{\mathbb{D}}{\mathrm{O}}$

method,
(iv) the state of the art for the estimation of $\frac{?}{\mathbb{Q}}$ conjugated bilirubin in plasma. 


\section{Material and methods}

AUSTRALIAN AND NEW ZEALAND SURVEY Two distributions were made to participants in the survey of Australian and New Zealand laboratories. The first was in June 1979, when four samples were distributed to 110 laboratories. Three samples were plasma from exchange transfusions and the fourth was a reconstituted lyophilised material, Precibil (Boehringer Mannheim GmbH, Biochemica, Mannheim, West Germany).

The second distribution was in November 1979. Five samples were distributed to 113 laboratories. Two were plasma from exchange transfusions, one was adult plasma with a high concentration of conjugated bilirubin and a fourth sample was reconstituted Precibil from the same batch as the June survey. The fifth sample was a primary bilirubin standard prepared from National Bureau of Standards Pure Bilirubin (Standard Reference Material 916; Office of Standard Reference Materials, Washington, USA) by dissolving the material in $2.0 \mathrm{ml}$ of $0.1 \mathrm{M}$ sodium carbonate and $1.5 \mathrm{ml}$ of $0 \cdot 1 M$ sodium hydroxide and diluting to $100 \mathrm{ml}$ with pooled sera; as per instructions provided with this material. Borate buffer $\mathrm{pH} 9.3$ (30.5 g/l dipotassium tetraborate) $; 3$ and a secondary standard of methyl orange, prepared by dissolving $238.8 \mathrm{mg}$ of dried, recrystallised methyl orange (May and Baker Laboratory Chemicals) in distilled water to a final volume of one litre, were also distributed.

Transport on both occasions was via express courier services. Participants were asked to assay samples immediately.

Table 1 shows the distribution of methods for

Table 1 Methods used for bilirubin analyses

\begin{tabular}{|c|c|c|}
\hline Mcthod & $\begin{array}{l}\text { Total } \\
\text { bilirubin }\end{array}$ & $\begin{array}{l}\text { Conjugated } \\
\text { bilirubin }\end{array}$ \\
\hline $\begin{array}{l}\text { Jendrassik and Grof } \\
\text { Malloy and Evelyn } \\
{ }^{6} \\
\text { Bilirubinometers } \\
\text { Spectrophotometric } \\
\text { Others }\end{array}$ & $\begin{array}{l}25 \\
20 \\
27 \\
12 \\
17\end{array}$ & $\begin{array}{l}38 \\
27 \\
- \\
-11\end{array}$ \\
\hline Total & 101 & 76 \\
\hline
\end{tabular}

plasma total bilirubin and conjugated bilirubin. Several different formulae were used by the spectrophotometric group and the "Others" group included a variety of diazo methods. A variety of materials were used as standards. Ten different commercial preparations and two pools of sera were used for internal quality control purposes by the participants.

REGIONAL SURVEY

"Elevated bilirubin control" (Ortho Diagnostics,
Raritan, New Jersey, USA) was distributed to South Australian laboratories on two occasions. The material was reconstituted in a central laboratory and received by participating laboratories on the morning of preparation. Borate buffer $\mathrm{pH}$ 9.3, a secondary methyl orange standard and a primary bilirubin standard as described above were also distributed. The bilirubin concentration in the samples provided was calculated using the two formulae recommended by Hertz et al. ${ }^{3}$ When a $1 / 41$ dilution in borate buffer and a $10 \mathrm{~mm}$ path length cuvette were used they were:

\section{Formula I}

$\left(\right.$ Abs $_{466} \times 21.6-$ Abs522 $\left._{52} 27.4\right) \times 41=\mu \mathrm{mol} / \mathrm{l}$

Formula II

$\left(\right.$ Abs $_{463} \times 19.9-$ Abs559 $\left._{53} 22.8\right) \times 41=\mu \mathrm{mol} / \mathrm{l}$

All specimens were prepared and distributed in liquid form. Care was taken to protect them from the light during and after preparation.

\section{Results and discussion}

One hundred and thirteen laboratories participated in the Australian and New Zealand survey. Results obtained previously from the South Australian regional group ${ }^{1}$ were unsatisfactory and it was considered necessary to investigate further the state of the art; this time obtaining information regarding the methods used, standardisation and quality control procedures from a larger group. We also wished to investigate whether our previous suggestions of method simplification and the use of a common standard by all participants would reduce this problem.

Table 2 shows the results obtained for the Precibil

Table 2 Results returned for Precibil (assigned value $327 \mathrm{\mu mol} / \mathrm{l}$ )

\begin{tabular}{llllll}
\hline Distribution & No of labs & Mean & $S D$ & \multicolumn{1}{c}{ CV \% } & Outlier \\
\cline { 2 - 6 } June 1979 & 100 & 328 & $24 \cdot 4$ & $7 \cdot 4$ & 1 \\
November 1979 & 93 & 324 & $30 \cdot 8$ & $9 \cdot 5$ & 3
\end{tabular}

In all calculations the mean and SD were calculated, outliers (results $>3 \mathrm{SD}$ from the mean) removed and the calculations repeated until all outliers were eliminated.

lyophilised control. We believed these results were unacceptable for patient care. The $95 \%$ confidence interval was 262 to $386 \mu \mathrm{mol} / \mathrm{l}$, and the possibility of reporting one of these two concentrations may lead to quite different clinical actions. This is an example of the problems that occur when a baby is transferred from one hospital to another. When these results were examined more carefully, on the basis of the method of analysis (Table 3 ), no one method group performed significantly better than any other. 
Table 3 Method comparison of results for the two distributions of Precibil

\begin{tabular}{llllrl}
\hline Method & No of labs & Mean & $S D$ & $C V \%$ & Outliers \\
\hline Jendrassik and Grof $^{5}$ & 25 & 337 & $24 \cdot 9$ & $7 \cdot 4$ & 0 \\
& 26 & 340 & $31 \cdot 2$ & $9 \cdot 2$ & 1 \\
Malloy and Evelyn $^{6}$ & 20 & 329 & $21 \cdot 1$ & $6 \cdot 4$ & 1 \\
& 17 & 329 & $32 \cdot 9$ & $10 \cdot 0$ & 1 \\
Bilirubinometers & 27 & 319 & $21 \cdot 9$ & $6 \cdot 9$ & 0 \\
& 22 & 311 & $14 \cdot 2$ & $4 \cdot 6$ & 1 \\
Spectrophotometric & 12 & 328 & $22 \cdot 0$ & $6 \cdot 7$ & 0 \\
& 10 & 313 & $33 \cdot 9$ & $10 \cdot 8$ & 0 \\
Others & 16 & 331 & $29 \cdot 4$ & $8 \cdot 8$ & 0 \\
& 18 & 319 & $38 \cdot 3$ & $12 \cdot 0$ & 0 \\
\hline
\end{tabular}

The true test of each laboratory's analyses is its performance with neonatal plasma. Table 4 summarises the results of these distributions. Once again the results were unacceptable for patient care. No individual method consistently produced the smallest interlaboratory variation (standard deviation).

Table 4 Results returned for the five neonatal plasma distributed

\begin{tabular}{llllll}
\hline Sample & No of labs & Mean & $S D$ & $C V \%$ & Outliers \\
\hline A & 101 & 109 & $12 \cdot 2$ & $11 \cdot 2$ & 1 \\
B & 101 & 200 & $16 \cdot 0$ & $8 \cdot 0$ & 0 \\
C & 101 & 288 & $23 \cdot 0$ & $8 \cdot 0$ & 1 \\
D & 96 & 156 & $14 \cdot 6$ & $9 \cdot 3$ & 1 \\
E & 91 & 232 & $17 \cdot 3$ & $7 \cdot 4$ & 6 \\
\hline
\end{tabular}

The variation found may be due to the inaccuracies of each participating laboratory and not due to intralaboratory imprecision. However, it is possible to gain an impression of the intralaboratory imprecision using the difference between duplicates formula $\left(\mathrm{SD}=\sqrt{\frac{\mathrm{d}^{2}}{2 \mathrm{n}}}\right)$. Table 5 shows the results of this approach and whilst these results (on only one pair of analyses) appear more clinically acceptable they do not achieve what we believe is the goal for these analyses, namely a coefficient of variation of $<2.5 \%$.
Table 5 Intralaboratory precision from duplicate analysis of Precibil

\begin{tabular}{lllll}
\hline Method & No of labs & SD & CV \%* & Outliers \\
\hline Jendrassik and Grof $^{5}$ & 17 & $15 \cdot 3$ & $4 \cdot 7$ & 4 \\
Malloy and Evelyn $^{6}$ & 13 & $12 \cdot 6$ & $3 \cdot 9$ & 2 \\
Bilirubinometers & 21 & $12 \cdot 4$ & $3 \cdot 8$ & 2 \\
Spectrophotometric & 9 & $21 \cdot 1$ & $6 \cdot 5$ & 0 \\
Others & 11 & $11 \cdot 4$ & $3 \cdot 5$ & 2
\end{tabular}

*The coefficient of variation was calculated using the assigned valuc of $327 \mu \mathrm{mol} / 1$.

STANDARDISATION PROCEDURE

Most laboratories were using commercial lyophilised material as a standard. Eleven laboratories were using some form of pure bilirubin standard. However, as a group they did not perform any better than those using other forms of standardisation. Following the previously reported improvement in group results when using a common standard $^{1}$ we further investigated the use of this approach. The commercial lyophilised material (Precibil, stated value $327 \mu \mathrm{mol} / \mathrm{l}$ ) and pure bilirubin standard (NBS material, weighed in value 356 $\mu \mathrm{mol} / \mathrm{l})$ distributed to participants were used to investigate two possible common standards. Table 6 summarises the results returned by participants for these two sera.

When comparing the results of the NBS standard for each method group both the Jendrassik and Grof ${ }^{5}$ and Malloy and Evelyn ${ }^{6}$ mean values were significantly higher $(\mathrm{p}<0.01)$ than $356 \mu \mathrm{mol} / \mathrm{l}$. However, the Bilirubinometer, "spectrophotometric" and "other methods" group mean values were not significantly different from the true value. This bias between methods poses problems when using NBS material as a common standard. When using this material as a standard, results for neonatal plasma were recalculated as follows:

"Standardised result" =

Participant's result for sample $\times$ value of standard Participant's result for standard

Table 6 Summary of results for Precibil and NBS standard

\begin{tabular}{|c|c|c|c|c|c|c|c|c|c|c|}
\hline \multirow[t]{2}{*}{ Method } & \multicolumn{5}{|c|}{ Precibil } & \multicolumn{5}{|c|}{ NBS standard } \\
\hline & $n$ & Mean & $S D$ & $\mathrm{CV} \%$ & Outliers & $n$ & Mean & $S D$ & $C V \%$ & Outliers \\
\hline All methods & $\begin{array}{r}100 \\
93\end{array}$ & $\begin{array}{l}328 \\
324\end{array}$ & $\begin{array}{l}24 \cdot 4 \\
30 \cdot 8\end{array}$ & $\begin{array}{l}7 \cdot 4 \\
9 \cdot 5\end{array}$ & $\begin{array}{l}1 \\
3\end{array}$ & 92 & 370 & $29 \cdot 5$ & $8 \cdot 0$ & 4 \\
\hline Jendrassik and Grof ${ }^{5}$ & $\begin{array}{l}25 \\
26\end{array}$ & $\begin{array}{l}337 \\
340\end{array}$ & $\begin{array}{l}24 \cdot 9 \\
31 \cdot 2\end{array}$ & $\begin{array}{l}7 \cdot 4 \\
9 \cdot 2\end{array}$ & $\begin{array}{l}0 \\
1\end{array}$ & 28 & 384 & $38 \cdot 2$ & $9 \cdot 9$ & 0 \\
\hline Malloy and Evelyn ${ }^{6}$ & $\begin{array}{l}20 \\
17\end{array}$ & $\begin{array}{l}329 \\
329\end{array}$ & $\begin{array}{l}21 \cdot 1 \\
32 \cdot 9\end{array}$ & $\begin{array}{r}6.4 \\
10.0\end{array}$ & 1 & 17 & 375 & $30 \cdot 5$ & $8 \cdot 1$ & 0 \\
\hline Bilirubinometer & $\begin{array}{l}27 \\
22\end{array}$ & $\begin{array}{l}319 \\
311\end{array}$ & $\begin{array}{l}21 \cdot 9 \\
14 \cdot 2\end{array}$ & $\begin{array}{l}6.9 \\
4.6\end{array}$ & $\begin{array}{l}0 \\
1\end{array}$ & 23 & 354 & $22 \cdot 9$ & $6 \cdot 5$ & 0 \\
\hline Spectrophotometric & $\begin{array}{l}12 \\
10\end{array}$ & $\begin{array}{l}328 \\
313\end{array}$ & $\begin{array}{l}22 \cdot 0 \\
33 \cdot 9\end{array}$ & $\begin{array}{r}6.7 \\
10.8\end{array}$ & $\begin{array}{l}0 \\
0\end{array}$ & 10 & 355 & $19 \cdot 8$ & $5 \cdot 6$ & 0 \\
\hline Others & $\begin{array}{l}16 \\
18\end{array}$ & $\begin{array}{l}331 \\
319\end{array}$ & $\begin{array}{l}29 \cdot 4 \\
38 \cdot 3\end{array}$ & $\begin{array}{r}8 \cdot 8 \\
12.0\end{array}$ & $\begin{array}{l}0 \\
0\end{array}$ & 17 & 369 & $42 \cdot 4$ & $11 \cdot 5$ & 0 \\
\hline
\end{tabular}


The interlaboratory variation of these "standardised results" for neonatal plasma from the group was significantly reduced for most methods by using this approach (Table 7). However because of the bias found with the Jendrassik \& Grof and Malloy \& Evelyn methods "standardisation" of these results significantly reduced the mean values compared with the Bilirubinometer and spectrophotometric methods. The use of this material as a common standard, although reducing the interlaboratory variation requires further investigation with respect to accuracy.

When the same approach was used with a commercial lyophilised sera (Precibil) similar results were obtained. Whilst the use of Precibil as a standard did reduce the interlaboratory variation of the group's results it was not as consistent as the NBS bilirubin. However, the Precibil control did not introduce such significant problems with bias as the NBS material.

The use of a common standard improved the performance of paediatric bilirubin analyses for the group, however, these results are still not adequate for patient care and further improvements should be sought.

\section{METHOD SIMPLIFICATION}

Hertz et $a l^{3}$ recommended the use of two formulae when using spectrophotometric methods. Eight laboratories in South Australia participated in a regional survey to examine these formulae and
Table 8 shows the results obtained for two pure bilirubin standards and Ortho "elevated bilirubin control". Coefficients of variation obtained suggested that there may be some potential for the use of these formulae by all laboratories in one region. The quality and maintenance of spectrophotometers would probably be a significant source of variation with these results. Consequently, provision of a common standard for this method should reduce the variation due to spectrophotometers and consequently the use of methyl orange was investigated. The absorption spectrum of methyl orange diluted $1 / 41$ in borate buffer is shown in Fig. 1. If methyl

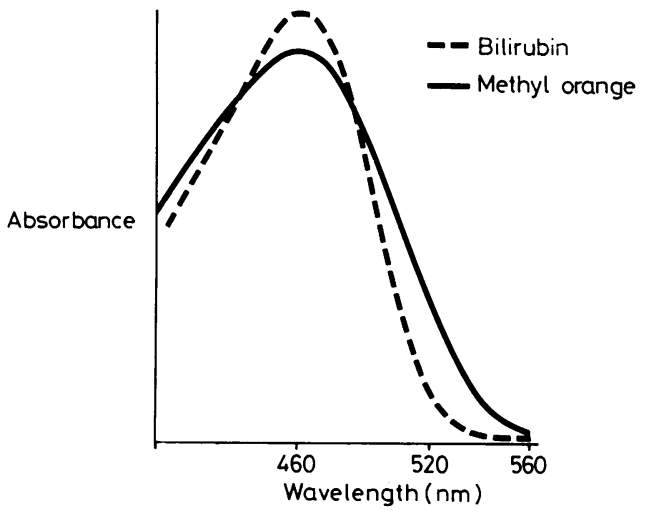

Fig 1 Absorytion spectrum of Methyl Orange in Borate Buffer

Table 7 Neonatal plasma results using the NBS bilirubin as a common standard

\begin{tabular}{|c|c|c|c|c|c|c|c|c|c|c|c|}
\hline \multirow[t]{2}{*}{ Method } & \multirow[t]{2}{*}{ Standardisation } & \multicolumn{5}{|c|}{ Sample D } & \multicolumn{5}{|c|}{ Sample E } \\
\hline & & $n$ & Mean & $S D$ & $C V \%$ & Outliers & $n$ & Mean & $S D$ & $C V \%$ & Outliers \\
\hline \multirow[t]{2}{*}{ All methods } & Raw data & 96 & 156 & $14 \cdot 6$ & $9 \cdot 3$ & 1 & 91 & 232 & $17 \cdot 3$ & $7 \cdot 4$ & 6 \\
\hline & NBS & 92 & 149 & $10 \cdot 6$ & $7 \cdot 1$ & 4 & 91 & 221 & $14 \cdot 6^{*}$ & $6 \cdot 6$ & 5 \\
\hline \multirow[t]{2}{*}{ Jendrassik and Grof ${ }^{5}$} & Raw data & 28 & 156 & $14 \cdot 4$ & $9 \cdot 2$ & 0 & 27 & 233 & $14 \cdot 7$ & $6 \cdot 3$ & 1 \\
\hline & NBS & 28 & 145 & $11 \cdot 4$ & 7.9 & 0 & 27 & 217 & $9 \cdot 4^{*}$ & $4 \cdot 3$ & 1 \\
\hline \multirow{2}{*}{ Malloy and Evelyn" } & Raw data & 18 & 157 & $14 \cdot 9$ & $9 \cdot 5$ & 0 & 18 & 237 & $28 \cdot 4$ & $12 \cdot 0$ & 0 \\
\hline & NBS & 17 & 147 & $5 \cdot 2^{*}$ & $3 \cdot 5$ & 0 & 15 & 216 & $6 \cdot 5^{*}$ & $3 \cdot 0$ & 2 \\
\hline \multirow[t]{2}{*}{ Bilirubinometer } & Raw data & 23 & 162 & $15 \cdot \overline{3}$ & $9 \cdot 5$ & 0 & 23 & 233 & $15 \cdot 5$ & $6 \cdot 6$ & 0 \\
\hline & NBS & 23 & 160 & $13 \cdot 5$ & $8 \cdot 4$ & 1 & 23 & 245 & $18 \cdot 2$ & $7 \cdot 8$ & 0 \\
\hline \multirow[t]{2}{*}{ Spectrophotometric } & Raw data & 10 & 154 & $13 \cdot 2$ & $8 \cdot 5$ & 0 & 10 & 226 & $21 \cdot 3$ & $9 \cdot 4$ & 0 \\
\hline & NBS & 10 & 154 & $7 \cdot 1^{*}$ & $4 \cdot 6$ & 0 & 10 & 226 & $11 \cdot 9^{*}$ & $5 \cdot 3$ & 0 \\
\hline
\end{tabular}

*Significantly reduced disparsion $(\mathrm{p}<0.05)$.

Table 8 Summary of the regional survey of direct spectrophotometric methods

\begin{tabular}{|c|c|c|c|c|c|c|}
\hline Sample & No of labs & Total no of results & Formula used & Mean & $S D$ & $C V \%$ \\
\hline Primary bilirubin standard I & 8 & 8 & $\begin{array}{l}\text { I }(466 / 522) \\
\text { II }(463 / 559) \\
\text { III (Methyl orange } 463 / 559)\end{array}$ & $\begin{array}{l}313 \\
337 \\
330\end{array}$ & $\begin{array}{l}18 \cdot 9 \\
18 \cdot 4 \\
12 \cdot 3\end{array}$ & $\begin{array}{l}6 \cdot 0 \\
5 \cdot 4 \\
3 \cdot 7\end{array}$ \\
\hline Primary bilirubin standard II & 8 & 8 & $\begin{array}{l}\text { I }(466 / 522) \\
\text { II }(463 / 559) \\
\text { III (Methyl orange } 463 / 559)\end{array}$ & $\begin{array}{l}323 \\
350 \\
350\end{array}$ & $\begin{array}{l}38 \cdot 7 \\
17 \cdot 5 \\
19 \cdot 6\end{array}$ & $\begin{array}{r}12 \cdot 0 \\
5 \cdot 0 \\
5 \cdot 6\end{array}$ \\
\hline $\begin{array}{l}\text { Ortho "elevated bilirubin control" } \\
\text { (two separate analyses) }\end{array}$ & 8 & 16 & $\begin{array}{l}\text { I }(466 / 522) \\
\text { II }(463 / 559) \\
\text { III (Methyl orange } 463 / 559)\end{array}$ & $\begin{array}{l}208 \\
219 \\
217\end{array}$ & $\begin{array}{r}8 \cdot 0 \\
10 \cdot 5 \\
6 \cdot 2\end{array}$ & $\begin{array}{l}3 \cdot 9 \\
4 \cdot 8 \\
2 \cdot 9\end{array}$ \\
\hline
\end{tabular}


orange is to be used as a secondary standard then it must mimic bilirubin in respect to its absorption spectrum, having a peak absorbance at approximately $460 \mathrm{~nm}$ and negligible absorption at the second wavelength where correction is made for haemoglobin, methaemalbumin, turbidity etc. Methyl orange absorbs significantly at $522 \mathrm{~nm}$ but not at $559 \mathrm{~nm}$. Consequently whilst formula II $(463 / 559)$ is suitable as a direct spectrophotometric method it is not suitable for use with a secondary methyl orange standard. Table 8 shows the results from the regional group using the following formula (III) to determine total bilirubin concentration. Formula III

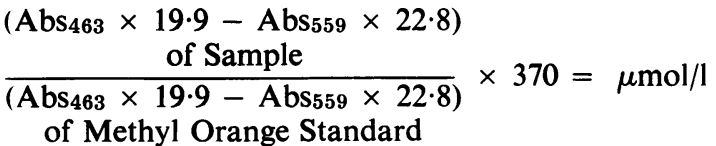

(the methyl orange was assigned a value of $370 \mu \mathrm{mol} / \mathrm{l})$.

Whilst this approach did not markedly reduce the dispersion of this group the results confirmed the use of the 463/559 formula and methyl orange as a secondary standard. This approach was therefore adopted in the Australian and New Zealand survey.

One hundred and thirteen laboratories in Australia and New Zealand were supplied with borate buffer, a methyl orange secondary standard and asked to analyse this standard and the sera distributed using the $463 / 559 \mathrm{~nm}$ spectrophotometric method described previously. Table 9 compares the results using Formula II with those obtained by the group (All methods) for the same material. The interlaboratory variation of results from Formula II was significantly reduced compared to the "All methods" results for the NBS standard, Precibil and one of the neonatal plasma distributed.

The mean value for the NBS standard $(359 \mu \mathrm{mol} / \mathrm{l})$ is not significantly different from the weighed-in value $(356 \mu \mathrm{mol} / \mathrm{l})$. This suggests that Formula II gives accurate results. However it should be noted that the "Precibil" value $(301 \mu \mathrm{mol} / \mathrm{l})$ was significantly $(\mathrm{p}<0.01)$ lower than the stated value of $327 \mu \mathrm{mol} / \mathrm{l}$; once again demonstrating a bias between the Jendrassik and Grof ${ }^{5}$ diazo coupling technique and the direct spectrophotometric assay.

In an effort to improve these results further, methyl orange was used as a standard as was previously discussed with the regional survey. The value $388 \mu \mathrm{mol} / \mathrm{l}$ obtained by the group was assigned to the methyl orange. This resulted in a further significant reduction in the interlaboratory variation when compared with the original data from all laboratories. When examining the absorbances reported by laboratories it was found that most of the outliers obtained were from isolated erroneous readings. Where a laboratory reported a generalised bias in the absorbances from all samples the methyl orange corrected these results in most cases (54 out of 57). The use of methyl orange therefore appears to correct for the deficiencies of most spectrophotometers in this survey. Similar improvements in interlaboratory variation were found when using either the NBS bilirubin or "Precibil" as a standard for the spectrophotometric method. However because of the stability of the methyl orange solution, the simplicity of preparation, and the absence of batch to batch variation we believe that the use of methyl orange will reduce standardisation problems. Consequently in reporting to participants of this survey we recommended that regional groups could use this approach with one central laboratory preparing the methyl orange secondary standard.

CONJUGATED BILIRUBIN

One of the problems with recommending a spectrophotometric method for total bilirubin is that a laboratory must have an alternate method for the estimation of conjugated bilirubin. Therefore although a laboratory may not be entirely satisfied

Table 9 Results from a common spectrophotometric method compared with "All methods" results

\begin{tabular}{|c|c|c|c|c|c|c|}
\hline Sample & Method & $n$ & Mean & $S D$ & $\mathrm{CV} \%$ & Outliers \\
\hline Methyl orange & Formula II 463/559 & 71 & 388 & $16 \cdot 1$ & $4 \cdot 2$ & 9 \\
\hline \multirow[t]{3}{*}{ NBS standard } & All methods & 92 & 370 & $29 \cdot 5$ & $8 \cdot 0$ & 4 \\
\hline & Formula II 463/559 & 76 & 359 & $24 \cdot 6^{*}$ & $6 \cdot 8$ & 4 \\
\hline & Methyl orange $463 / 559$ & 76 & 364 & $16 \cdot 1^{*}$ & $4 \cdot 4$ & 3 \\
\hline \multirow[t]{3}{*}{ Precibil control } & All methods & 93 & 324 & $30 \cdot 8$ & $9 \cdot 5$ & 3 \\
\hline & Formula II 463/559 & 71 & 301 & $20.5+$ & $6 \cdot 8$ & 6 \\
\hline & Methyl orange $463 / 559$ & 72 & 303 & $15 \cdot 6+$ & $5 \cdot 2$ & 4 \\
\hline \multirow[t]{3}{*}{ Neonatal plasma D } & All methods & 96 & 156 & $14 \cdot 6$ & $9 \cdot 3$ & 1 \\
\hline & Formula II $463 / 559$ & 73 & 147 & $11 \cdot 4^{*}$ & $7 \cdot 8$ & 7 \\
\hline & Methyl orange $463 / 559$ & 72 & 149 & $8 \cdot 0 \dagger$ & $5 \cdot 4$ & 7 \\
\hline \multirow[t]{3}{*}{ Neonatal plasma $\mathrm{E}$} & All methods & 91 & 232 & $17 \cdot 3$ & $7 \cdot 4$ & 6 \\
\hline & Formula 11 463/599 & 76 & 220 & $18 \cdot 5$ & $8 \cdot 4$ & 4 \\
\hline & Methyl orange $463 / 559$ & 73 & 223 & $10 \cdot 0 \dagger$ & $4 \cdot 5$ & 6 \\
\hline
\end{tabular}

Significantly reduced dispersion $* \mathrm{p}<0.05 .+\mathrm{p}<0.01$. 


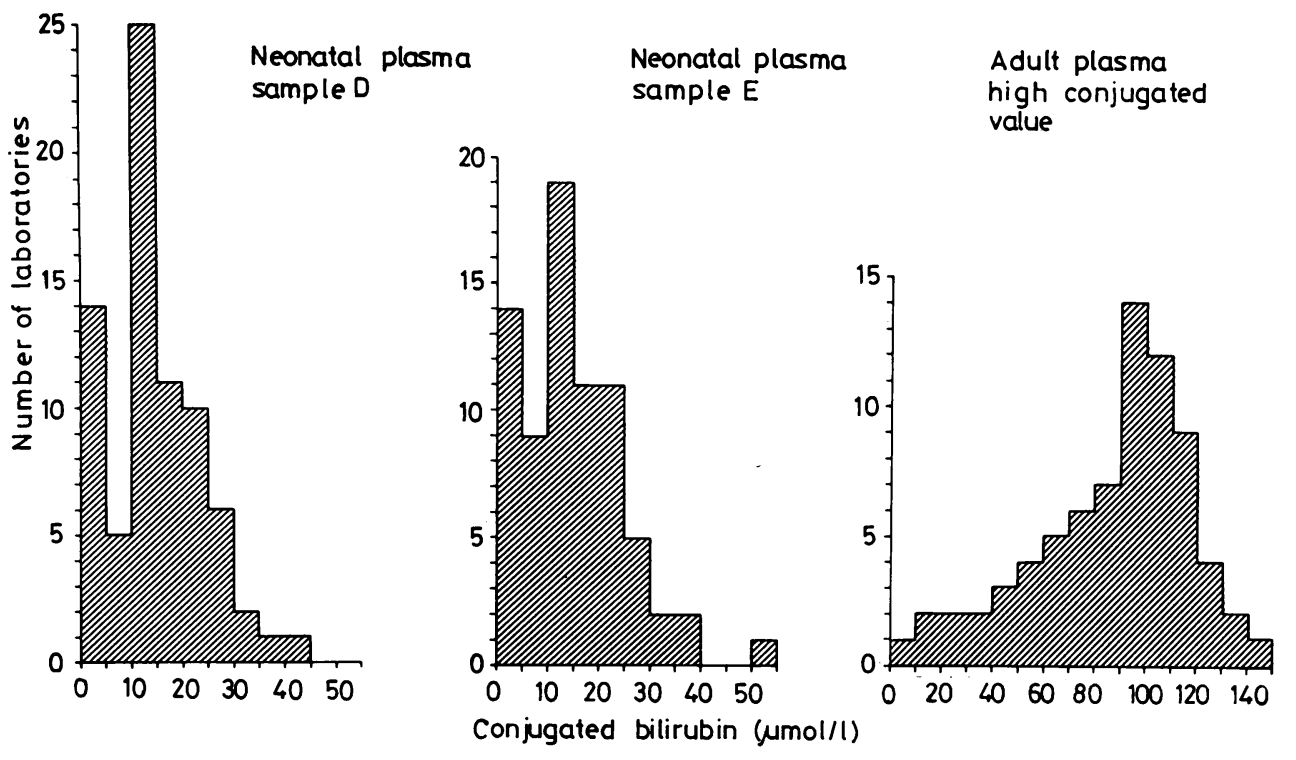

Fig 2 Distribution of Results for Conjugated Bilirubin Estimations

with its analyses for total bilirubin it may continue to use a relatively unsatisfactory method in order to continue to provide a conjugated bilirubin determination. Consequently we surveyed the state of the art for these analyses. Fig. 2 shows the distributions of results obtained with two neonatal plasma and one adult plasma having a high concentration of conjugated bilirubin.

If this survey reflects the state of the art for conjugaged bilirubin analyses then it is obvious that laboratories are unable to report accurately conjugated bilirubin results. In view of these results we question the practice of reporting apparently accurate results when it appears that at best the results reported are only an approximation to the true value. We believe a more responsible approach would be to rank conjugated bilirubin results as follows $(\mu \mathrm{mol} / \mathrm{l})$ :

$$
\begin{gathered}
<25 \\
25-50 \\
50-100 \\
100-150 \\
150-200
\end{gathered}
$$

This approach should be adequate for patient care and not lead to overinterpretation of results.

Another factor in the use of conjugated bilirubin results is the frequency with which the laboratory is required to perform this assay. Participants in this survey varied from "not at all" to "with every total bilirubin." We believe that a discretionary rather than screening approach is necessary particularly as more blood is required from the patient for each conjugated bilirubin analysis. Obviously the question of the frequency of analysis must be discussed with clinical staff but if the frequency of results for conjugated bilirubin estimation is reduced then a simple diazo coupling method could be used. Consideration regarding the most suitable method for total bilirubin estimation, where results must be both precise and accurate, can then include spectrophotometric methods which at present appear to provide the most acceptable performance.

\section{Conclusions}

Our primary aim during these investigations has been to demonstrate the advantages of method simplification. We have shown that using the spectrophotometric method in conjunction with a methyl orange standard can produce accurate results with reduced imprecision, although improvement in the latter was not as significant in the Australian and New Zealand group as within the smaller regional group of laboratories. Objections to using a spectrophotometric method are that it cannot measure the relative amounts of conjugated and unconjugated bilirubin present in any patient sample but it is our belief that precise measurement of conjugated bilirubin is probably not necessary and in fact our survey showed that the reporting of apparently precise results may not be valid with the methods used at present. We are sure that laboratories can 
maintain a method that will give an approximation of the plasma concentration of conjugated bilirubin which would be adequate for patient care and therefore the method used for conjugated bilirubin analysis should not affect the decision of which method to use for total bilirubin analysis.

We are most grateful for the work by the laboratories who participated in the surveys. We would also wish to acknowledge the assistance of the Australian Association of Clinical Biochemists and the Royal College of Pathologists of Australia on whose behalf we carried out the Australian and New Zealand surveys.
References

${ }^{1}$ St John A, Penberthy LA. An interlaboratory survey of paediatric bilirubin analyses. J Clin Pathol 1979;32:794-7.

${ }^{2}$ Blijenberg BG, Leijnse B. A survey report on the determination of total bilirubin in neonatal samples. $J$ Clin Chem Clin Biochem 1980;18:27-30.

${ }^{3}$ Hertz H, Dybkaer R, Lauritzen M. Direct spectrophotometric determination of the concentration of bilirubins in serum. Scand J Clin Lab Invest 1974;33:215-30.

+ Jackson SH. A direct-reading bilirubinometer incorporating hemolysis and turbidity correction. Clin Chem 1965; $\overrightarrow{0}$ 2:1051-7.

5 Jendrassik L, Grof P. Vereinfachte photometrische Methode zur Beistimmung des Bilirubins. Biochem Zscht 1938; హ్ 297:81-9.

${ }^{6}$ Malloy HT, Evelyn KA. The determination of bilirubin with the photoelectric colorimeter. J Biol Chem 1937: w 119:481-90.

\section{Reports and Bulletins prepared by the Association of Clinical Biochemists $\overrightarrow{\mathrm{s}}$}

The following reports and bulletins are published by the Association of Clinical Biochemists. They may be obtained from The Publishing Department, British Medical Journal (ACB Technical Bulletins), BMA House, Tavistock Square, London WC1H 9JR. Overseas readers should remit by British Postal or Money Order.

SCIENTIFIC REVIEWS (price $£ 1 \cdot 00 / \$ 2.00$ each)

1 The assessment of thyroid function March 1971 FV FLYNN and JR HOBBS

2 Renal function tests suitable for clinical practice January 1972 FL MITCHELL, N VEALL, and RWE WATTS

3 Biochemical tests for the assessment of fetoplacental function May 1975 CE WILDE and RE OAKEY

4 Test of exocrine pancreatic function March 1977 AH GOWENLOCK

5 Assay of cholinesterase in clinical chemistry March 1979 ELSIE SILK, J KING, and MARY WHITTAKER

TECHNICAL BULLETINS (price $£ 1 \cdot 00 / \$ 2.00$ each)

22 Bilirubin standards and the determination of bilirubin by manual and technicon AutoAnalyzer methods January 1971 BARBARA BILLING, RUTH HASLAM, and N WALD

23 Intcrchangeable cells for spectrophotometers and fluorimeters September 1971 SS BROWN and AH GOWENLOCK

24 Simple tests to detect poisons March 1972 BW MEADE et al.

25 Blood gas analysers May 1972 K DIxON

26 Kits for enzyme activity determination September 1972 SB ROSALKI and D TARLOW

27 Assessment of pumps suitable for incorporation into existing continuous flow analytical systems November 1972 A FLECK et al.

28 Routine clinical measurements of transferrin in human serum September 1973 K DIXON
29 Control materials for clinical biochemistry (5th edition) September 1973 JF STEVENS

30 Notes on the quality of performance of serum cholesterol assays September 1973 SS BROWN

31 Determination of uric acid in blood and in urine July 1974 RWE WATTS

32 A survey of amino acid analysers readily available in the United Kingdom September 1974 JE CARLYLE and P PURKISS

33 Definitions of some words and terms used in automated analy'sis November 1974 A FLECK, R ROBINSON, SS BROWN, and JR HOBBS

34 Measurement of albumin in the sera of patients January 1975 LINDA SLATER, PM CARTER, and JR HOBBS 35 Investigation of the validity of temperature correction $\stackrel{8}{\rho}$ factors for serum aspartate and alanine transaminases March 1975 SB ROSALKI et al.

36 Factors influencing the assay of creatinine November 1975 JGH COOK

37 A survey of enzyme reaction rate analysers readily $N$ available in the United Kingdom July 1977 RA SAUNDERS and RF BURNS

38 Transport of specimens for clinical chemistry an- $N$ alysis November 1977 P WILDING, JF ZILVA, and CE WILDE

39 A scheme for the evaluation of diagnostic kits May 1978 PH LLOYD

40 A practical guide to gamma-counting in radio- 0 immunoassay January 1980 CE WILDE and D OTTEWELL $\frac{P}{\mathbb{D}}$ 41 The use of biochemical tests in the diagnosis of $\stackrel{P}{P}$ disorders of calcium metabolism July 1980 ANGELA $\stackrel{\square}{\square}$ FAIRNEY 